Elżbieta BUCHCIC

IB UH-P Kielce

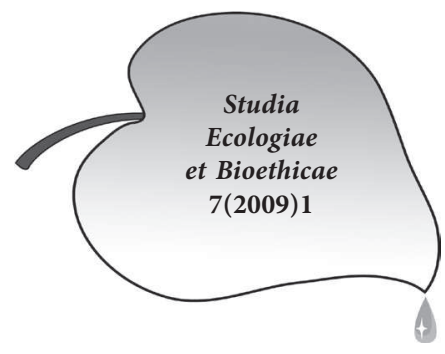

\title{
Edukacja ekologiczna priorytetem wykształcenia współczesnego człowieka
}

„Człowiek jako jednostka biopsychospołeczna w ciagu swego rozwoju przejawia określona aktywność oraz podlega wpływom oddziaływania środowiska, w którym żyje i działa. Jedna z form jego działalności jest edukacja, której wynikiem jest określony poziom i charakter świadomości jednostki ludzkiej oraz jej kultury.”

J.Frątczak

\section{Wstęp}

$\mathrm{Z}$ pojęciem edukacji każdy człowiek $\mathrm{w}$ dzisiejszych czasach spotyka się bardzo często. Edukacja formalna, czyli taka, z którą każdy miał do czynienia $\mathrm{w}$ szkole, $\mathrm{w}$ trakcie studiów oraz $\mathrm{w}$ ramach różnego typu szkoleń, nie może być jednak dla nas jedynym źródłem kształcenia. Najważniejsza jest, bowiem ta wiedza, która w życiu najbardziej nam się przyda, a także taka, którą przyswajamy najchętniej. I tu właśnie pojawia się edukacja nieformalna. Współczesny człowiek praktycznie podlega jej wszędzie. Proces kształtowania postaw, wartości, a także umiejętności i wiedzy trwa przez całe życie. Różne doświadczenia oraz wpływ edukacyjny otoczenia, głównie rodziny, środowiska pracy, a także mass mediów, kształtują nasz charakter i to jak będziemy postrzegać świat.

We współczesnym świecie mass media są bardzo rozpowszechnione i pełnią one ogromną rolę w edukowaniu społeczeństwa. Za pomocą telewizji, radia i Internetu można w ciekawy sposób przedstawić środowisko naturalne i jego problemy. Bardzo ważną zaletą takiego zdobywania wiedzy jest to, że każdy może wybrać sobie takie programy telewizyjne, audycje radiowe i strony internetowe, które będą poszerzały jego indywidualne zainteresowania. Nie narzuca się konkretnego formatu, nie ma osoby, która przekazuje z góry określone informacje. Trzeba także pamiętać, że nie każdy ma równe szanse w zdobywaniu wiedzy w systemie edukacji formalnej. Edukacja nieformalna uzupełnia niejako system edukacji formalnej. Wyrównuje szanse osób, które nie miały możliwości pełnego kształcenia w systemie edukacji formalnej. 
Są oczywiście także wady edukacji nieformalnej. Należą do nich głównie rzetelność i wiarygodność podawanych informacji, brak formalnego uznania, a także koszty związane $\mathrm{z}$ dostępem do poszczególnych form mass mediów.

Zdawałoby się, że sprawy środowiska lokalnego powinny w dużym stopniu interesować społeczeństwo. Czy jednak tak się dzieje? Coraz częściej problemy przyrody są odstawiane na dalszy plan, nie poświęca się im zbyt wiele uwagi. Człowiek nigdy nie przestaje się uczyć i rozwijać. Edukacja towarzyszy nam w różnych sferach i momentach życia. Uczenie kojarzy nam się głównie ze szkołą, ale nie powinniśmy zaniedbywać nauki, która ma miejsce już poza jej murami. To, czego się uczymy, przyczynia się w dużym stopniu do tego, jakimi ludźmi jesteśmy. Im większą wiedzę posiadamy, tym większa jest nasza świadomość dotycząca rozwoju otaczającego nas świata, zrozumienia zjawisk, jakie wokół nas zachodzą, co z kolei pozwala nam na pełny udział w społeczeństwie.

\section{Edukacja a świadomość ekologiczna}

„Człowiek, jak każdy żywy organizm, jest elementem środowiska i podlega jego prawom. Nauką o związkach, współzależnościach między organizmami a otaczającym je środowiskiem to ekologia. Termin ,ekologia” pochodzi od greckich słów: oikos, co oznacza dom, miejsce życia, i logos - słowo, nauka; tak więc dosłownie ekologia oznacza naukę o miejscu życia organizmów. Termin ten wprowadził po raz pierwszy niemiecki zoolog Ernst Haeckel w 1869 r." ${ }^{1}$

„Stopień degradacji środowiska naturalnego, jaki dokonał się w ostatnich dziesięcioleciach, zwrócił uwagę opinii publicznej wielu społeczeństw na problemy związane ze skutkami niekontrolowanego rozwoju cywilizacji. Pogarszający się stan środowiska nakazuje konieczność szeroko rozumianej edukacji ekologicznej wszystkich grup społecznych i zawodowych".

„Edukacja środowiskowa oznacza przedmiot nauczania i działalność wychowawczą, przygotowującą do rozwiązywania praktycznych problemów środowiskowych przez interdyscyplinarne podejście, poczucie odpowiedzialności oraz czynne włączenie się każdego człowieka i zbiorowości we wspólne działanie.”³

„Edukacja ekologiczna (środowiskowa) jest koncepcją kształcenia i wychowania $\mathrm{w}$ duchu poszanowania środowiska przyrodniczego oraz kształtowania poglądów społeczeństwa względem otaczającego świata. Dotyczy rozbudzania

1 L. Tuszyńska, Edukacja Ekologiczna dla nauczycieli i studentów, Wyższa Szkoła Pedagogiczna Towarzystwa Wiedzy Powszechnej Warszawa 2006, s. 18.

2 M. PARLAK, Edukacja ekologiczna w procesie kształcenia wczesnoszkolnego - założenia, program, propozycje metodyczne, Wydawnictwo Pedagogiczne ZNP Kielce 2005, s. 9.

3 R. OlaczeK, Słownik szkolny. Ochrona przyrody i środowiska. WSiP Warszawa 1999, s. 61. 
wrażliwości na problemy środowiska, poszukiwania przyczyn i przewidywania skutków zjawisk prowadzących do degradacji środowiska naturalnego".

Człowiek jest nierozerwalnie związany z przyrodą i wszelka jego działalność ma odzwierciedlenie w otaczającym nas środowisku. Dlatego ważną rzeczą jest uświadamianie społeczeństwa w zakresie możliwości i sposobów jak najmniej szkodliwego funkcjonowania i korzystania $\mathrm{z}$ dobrodziejstw natury. Taka działalność człowieka nazywana jest w literaturze przedmiotu rozwojem zrównoważonym. Polega ona na ,prowadzeniu wszelkiej działalności gospodarczej w harmonii z przyrodą, czyli tak, aby nie spowodować w niej nieodwracalnych zmian". ${ }^{5}$ Konieczne jest również uzmysłowienie dalekowzroczności tych działań, ze środowiska korzystamy nie tylko my, ale też następne pokolenia.

„(...) Powszechnie wyodrębnia się trzy główne obszary, na których należy skoncentrować się przy planowaniu skutecznej strategii osiągnięcia zrównoważonego rozwoju. Są to: ochrona środowiska i racjonalna gospodarka zasobami naturalnymi (m.in. ograniczanie zanieczyszczenia środowiska, ochrona zagrożonych wyginięciem gatunków zwierząt i roślin, promocja odnawialnych źródeł energii), wzrost gospodarczy i sprawiedliwy podział korzyści z niego wynikających (m. in. ułatwienie dostępu do rynków dla państw rozwijających się, finansowanie rozwoju, zmiana nieracjonalnych wzorców konsumpcji i produkcji) oraz rozwój społeczny (m.in. walka z ubóstwem, dostęp do edukacji, ochrony zdrowia)".6

Dla przetrwania życia na Ziemi niezbędne jest kształtowanie świadomości ekologicznej. „,Upowszechnianie w społeczeństwie świadomości ekologicznej jest podstawowym warunkiem ekorozwoju. Kształtowaniu świadomości ekologicznej służyć powinny wychowanie ekologiczne i powszechna oświata w dziedzinie ochrony środowiska, realizowane przez szkolnictwo różnych szczebli, organizacje i instytucje społeczne oraz środki masowego przekazu". ${ }^{7}$

„Świadomość ekologiczna, rozumiana jako obszar świadomości społecznej odniesionej do środowiska przyrodniczego, przejawia się zarówno w myśleniu, jak i przeżyciach oraz w społecznych standardach pojmowania, przeżywania i wartościowania biosfery. Składnikami świadomości ekologicznej są określone treści, nastawienia oraz emocje, dotyczące środowiska przyrodniczego, powiązane i wzajemnie przenikające się z innymi formami świadomości społecznej”."

Według H. Skolimowskiego świadomość ekologiczna powinna być:

- holistyczna - otaczający nas świat rozumie jako całość do której należy też człowiek, która posiada cechy organizmu żywego,

\footnotetext{
L. TUSZYŃsKa, op. cit., s. 5.

D. Cichy, Skuteczność kształcenia dla ekorozwoju, Biologia w Szkole, 1995, nr 5.

http://www.poznajmyonz.pl/index.php?document=41

M. KALIŃsKI, Edukacja ekologiczna formą przystosowania obronnego, [w:] „Edukacja i Dialog”, 1995 nr 6.

8 L. TuszyńsKa, op. cit., s. 7.
} 
- jakościowa - w jedności i nierozerwalności świata widzi przede wszystkim związki jakościowe,

- duchowa - związana z duchowością człowieka a nie tylko z jego umysłem,

- referencyjna - charakteryzująca się czcią i szacunkiem dla wszystkiego co istnieje,

- uczestnicząca - człowiek aktywnie uczestniczy w życiu naszej planety, nie jest biernym obserwatorem,

- ewolucyjna - ,przebieg procesów w kosmosie jest ukierunkowany od jednostajności do różnorodności, od materialności do duchowości, a więc ewolucja kosmosu - jako całości dostępnej ludzkiemu poznaniu - przedstawia zjawisko rozprzestrzeniania się procesów psychicznych, duchowych".

„Podłożem świadomości ekologicznej jest wiedza nabyta w szkole i poza nią, tradycja kulturowa określonej grupy społecznej, presja opinii tej grupy, własne doświadczenia itp. Treścią świadomości ekologicznej są m.in.: prawa człowieka do środowiska, znajomość zagrożeń, ich przyczyn i skutków, poczucie własnej odpowiedzialności za stan przyrody, wola działania połączona z wiarą, że warto chronić przyrodę"."

„(...) Praca nad kształtowaniem świadomości wytworzy kulturę ekologiczna jednostki, na którą złożą się następujące elementy:

- całokształt wiedzy o środowisku przyrodniczym,

- zdolność dostrzegania specyfiki i złożoności zjawisk przyrodniczych oraz odnajdywania w nich głównych zjawisk, współzależności i prawidłowości,

- gotowość do przejawiania określonych zachowań w stosunku do środowiska przyrodniczego,

- zdolność otwartego, twórczego myślenia, warunkująca podatność na wprowadzenie innowacji gwarantujących zwiększenie bezpieczeństwa ekologicznego,

- ukształtowanie wrażliwości i zdolności postrzegania problemów środowiska we własnej pracy i życiu". ${ }^{11}$

\section{Czynniki kształtujące społeczeństwo ekologiczne}

Poszerzanie świadomości, uwrażliwianie społeczeństwa oraz angażowanie w działalność ekologiczną powoduje kształtowanie postaw, wartości i niezbędnych umiejętności potrzebnych do wprowadzenie w życie codzienne zasady zrównoważonego rozwoju.

Według Dołęgi edukacyjna problematyka ekofilozofii dotyczy przede wszystkim podstaw filozoficznych wychowania proekologicznego, a ściślej mówiąc wy-

\footnotetext{
M. PARLAK, op. cit., s. 13.

10 L. TuszyŃsKa, op. cit., s. 8.

11 D. Сıсну, Koncepcje społecznej edukacji ekologicznej. Biologia w Szkole nr 5, s. 278.
} 
chowania sozologicznego $\mathrm{w}$ rodzinie, $\mathrm{w}$ szkole, $\mathrm{w}$ masmediach, $\mathrm{w}$ organizacjach społecznych, religiach oraz w ogólnej edukacji narodowej. Kształtowanie świadomości wrażliwej na wartość środowiska społeczno-przyrodniczego zależy również od programów nauczania w przedszkolach, szkołach podstawowych, ponadgimnazjalnych i na uczelniach wyższych oraz od powszechnej edukacji ekologicznej dorosłych. Ponadto jest to priorytetowe zadanie dla wszystkich zdających sobie sprawę z jakości aktualnego środowiska i jego wpływu na życie na naszej Planecie oraz z jego wpływu na życie i zdrowie człowieka w naszej Ojczyźnie, jak i na całym świecie. Jest to zadanie nie tylko dla filozofów, ale dla tych wszystkich, którzy mają wpływ na świadomość społeczną w Polsce i na świecie. ${ }^{12}$

W potocznym rozumieniu są to wszelkie formy działalności skierowanej do społeczeństwa, ze szczególnym uwzględnieniem dzieci i młodzieży, które mają na celu wpływanie na poziom świadomości ekologicznej, propagowanie konkretnych zachowań korzystnych dla środowiska naturalnego, upowszechnianie wiedzy o przyrodzie.

Rycina 1. Czynniki kształtujące społeczeństwo ekologiczne
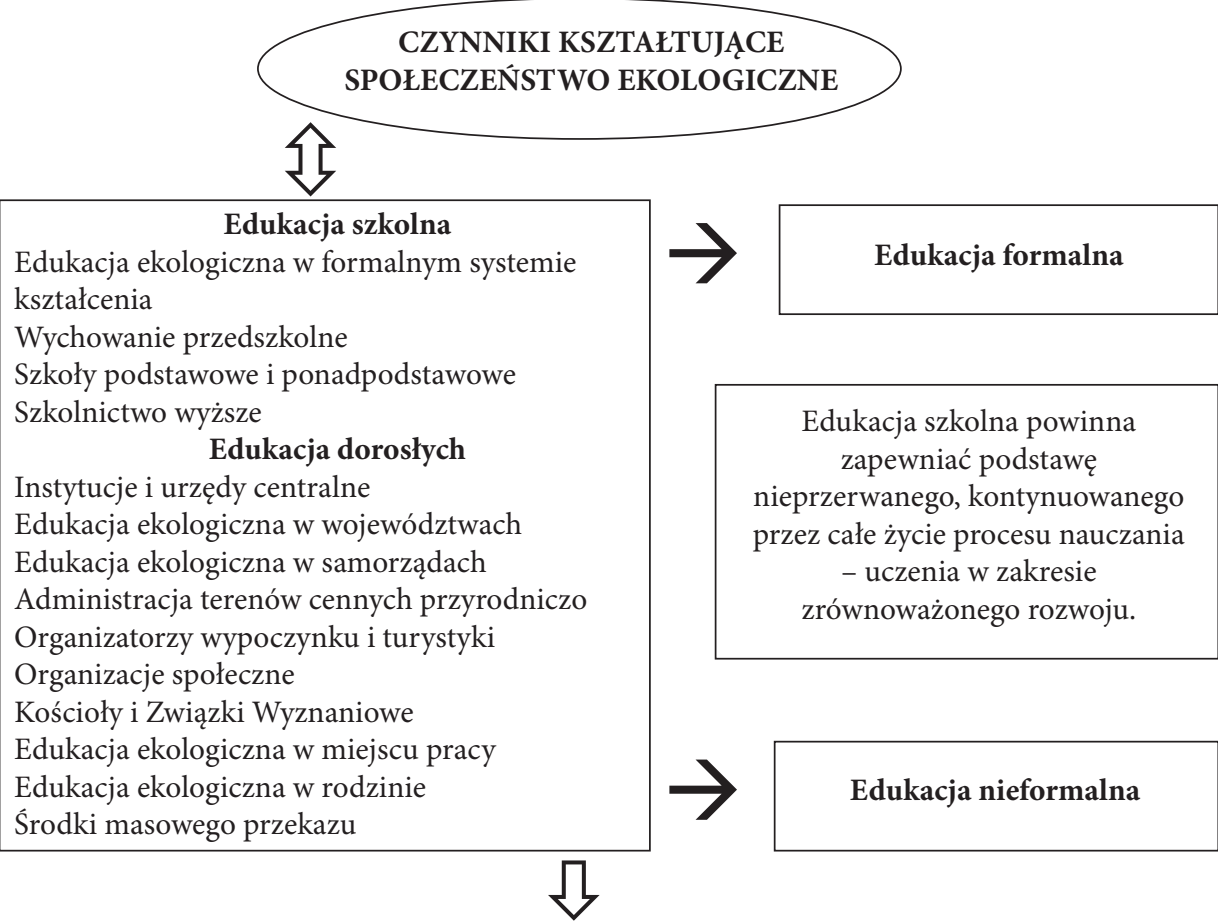

12 J. M. DoŁĘGA, Z filozofii nauk ekologicznych. [w:] Ochrona środowiska społeczno - przyrodniczego w filozofii i teologii. Wydawnictwo Uniwersytetu Kardynała Stefana Wyszyńskiego. Warszawa 2003, s. 35-36. 
Elżbieta Buchcic

\section{Kształcenie ustawiczne}

Czynniki wpływające na efektywności edukacji ekologicznej:

$\rightarrow$ promowanie najskuteczniejszych form i najważniejszych treści,

$\rightarrow$ wskazanie sposobów optymalnej alokacji środków finansowych,

$\rightarrow$ uporządkowanie przepływu informacji i usprawnienie procesu decyzyjnego

związanego z edukacją.

Powyższe cele powinny być osiągane przy wykorzystaniu najlepszych krajowych i zagranicznych doświadczeń

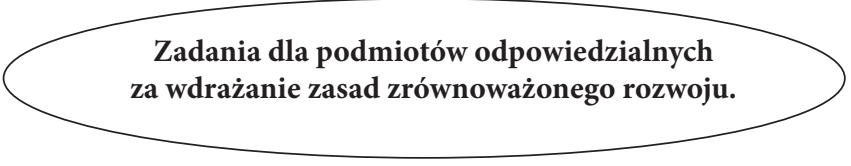

Rodzina

$\rightarrow$ pozytywne wzorce zachowań zgodne $\mathrm{z}$ zasadami rozwoju zrównoważonego w życiu codziennym, np.: segregacja odpadów, oszczędzanie wody i energii, szacunek dla przyrody

$\rightarrow$ umożliwienie dzieciom rozwijania zainteresowań związanych z ochroną środowiska, przy współpracy organizacji społecznych, samorządów

$\rightarrow$ kształtowanie prawidłowych postaw ekologicznych?

Autorzy i wydawcy publikacji zwartych związanych z rozwojem edukacji ekologicznej.

$\rightarrow$ szeroka oferta prawidłowo opracowanych pod względem metodycznym i merytorycznym materiałów

$\rightarrow$ trafna oferta i łatwo dostępna

$\rightarrow$ informacje praktyczne wynikające $\mathrm{z}$ doświadczenia dydaktycznego autorów

$\rightarrow$ teksty uzupełnione zestawami plansz, folii, zapisami elektronicznymi, programami komputerowymi itd.

\section{Edukatorzy prowadzący zajęcia w terenie}

$\rightarrow$ realizacja programów ściśle wykorzystujące walory i możliwości danego terenu

Zajęcia powinny być:

$\rightarrow$ zaplanowane, ale umożliwiające spontaniczne odkrycia przy okazji formułowania pytań i grupowania problemów

$\rightarrow$ urozmaicone tematycznie z odniesieniami przyrodniczymi, historycznymi, estetycznymi a nawet osobistymi

$\rightarrow$ zachęcające do indywidualnego, bezpośredniego studiowania krajobrazu

$\rightarrow$ zapewniające organizacyjny profesjonalizm oraz pełne bezpieczeństwo zajęć 


\section{Duchowni i katecheci}

$\rightarrow$ realizacja niezależnej edukacji związanej z zasadami wiary

$\rightarrow$ prowadzone nauczanie powinno sięgać do wzorców moralnej odpowiedzialności za słowa i czyny oraz do aksjomatów dobroci i miłości

$\rightarrow$ wykorzystywanie doświadczeń wynikających z ducha ekumenizmu, afirmacja życia

Pracownicy policji, straży miejskiej, straży pożarnej, służby leśnej

$\rightarrow$ edukacja ekologiczna w komponowana w program służby

$\rightarrow$ stały nadzór nad kształtowaniem poprawnego wizerunku ekologicznego miejsca i podejmowanych działań w terenie

$\rightarrow$ respektowanie przepisów ochrony środowiska

$\rightarrow$ specjalnie przygotowane publikacje. broszury zawierające niezbędne informacje

Redaktorzy audycji radiowych

$\rightarrow$ wiadomości regionalne zestawiane we współpracy z lokalnymi organizacjami, oraz indywidualnymi sobami działającymi na rzecz ochrony środowiska

$\rightarrow$ autentyzm, zachęta do działań i poznawania przyrody

$\rightarrow$ dobre rady i rozmowy z ludźmi zajmującymi się tą problematyką

$\rightarrow$ wyszukiwanie ekologicznych zainteresowań u znanych i powszechnie szanowanych osób

\section{Pracodawcy}

$\rightarrow$ permanentna informacja o działaniach organów zarządzających instytucją w dziedzinie poprawy ekologicznego wizerunku firmy z argumentacją społeczną i ekonomiczną

$\rightarrow$ zwracanie uwagi na tendencje korzystne dla środowiska i pracowników

$\rightarrow$ eksponowanie rzeczywiście istniejących problemów środowiskowych związanych z działalnością firmy

$\rightarrow$ organizacja masowych imprez, wprowadzenie wyraźnych ekologicznych akcentów

$\rightarrow$ dążenie do zysków ekonomicznych bez strat w środowisku

\section{Wydawcy i redaktorzy periodyków}

$\rightarrow$ najwyższej jakości artykuły dobrych publicystów

$\rightarrow$ prezentacja znanych ludzi działających na rzecz środowiska

$\rightarrow$ piękne fotografie przyrodnicze, promujące szczególnie polski krajobraz

$\rightarrow$ konkursy dla różnych grup społecznych i zawodowych

\section{Wydawcy i redaktorzy prasy codziennej}

$\rightarrow$ rzetelna informacja bez aspektów sensacji

$\rightarrow$ cykle popularyzujące oczekiwane zachowania proekologiczne w społeczeństwie

$\rightarrow$ informacja naukowa i popularnonaukowa dotycząca problemów ochrony i kształtowania środowiska

$\rightarrow$ promowanie regionalnych i lokalnych inicjatyw służących wdrażaniu idei rozwoju zrównoważonego

$\rightarrow$ cykle tematyczne, które zyskają stałych czytelników 


\section{Redaktorzy programów telewizyjnych}

$\rightarrow$ rzetelna informacja w audycjach publicystycznych

$\rightarrow$ programy powinny zawierać tylko prezentację i ewentualnie poważną dyskusję rzeczową

$\rightarrow$ prezentowanie wyważonych komentarzy

$\rightarrow$ atrakcyjne audycje publicystyczne i przyrodnicze, filmy, video clipy z humorem, ale i z refleksją poruszające najciekawsze kwestie ekologiczne

$\rightarrow$ rezygnacja z reportaży eksponujących nie meritum spraw, a formę konfliktów

$\rightarrow$ filmy przyrodnicze opatrzone oryginalnymi, bogatymi merytoryczne komentarzami przygotowanymi przez specjalistów

\section{Urzędnicy}

$\rightarrow$ zasady rozwoju zrównoważonego powinny być znane wszystkim pracownikom rządowym i samorządowym

$\rightarrow$ wiedzę należy stale wzbogacać i wykorzystywać przy różnego rodzaju kontaktach zawodowych, podejmowaniu i uzasadnianiu decyzji

$\rightarrow$ rzetelna znajomości regionalnych i lokalnych problemów ekologicznych

$\rightarrow$ w zakresie organizacyjnym istotną kwestią jest możliwość wykorzystywanie kadry urzędniczej do procesu edukacji ekologicznej społeczeństwa

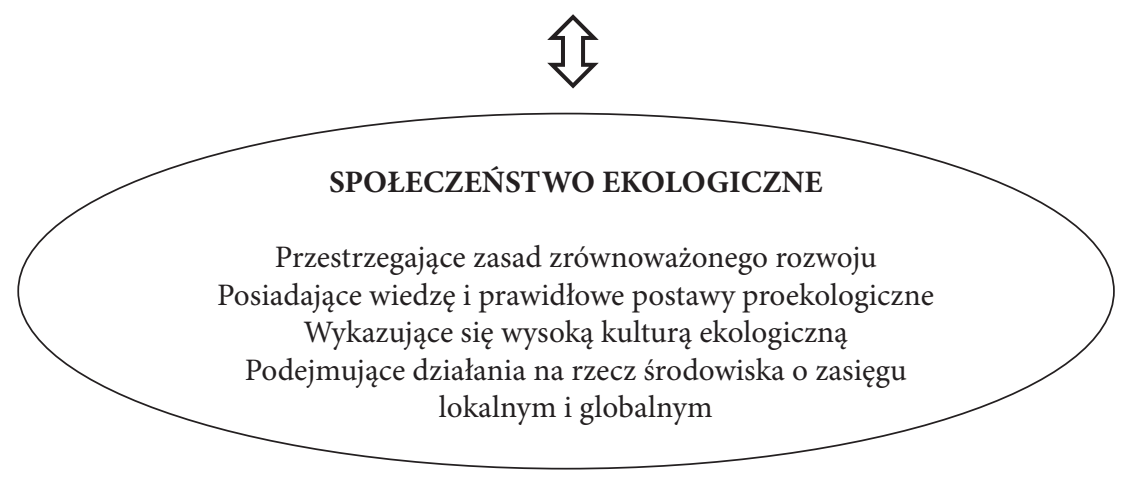

Ważne jest, aby stworzyć taki system kształcenia ekologicznego, w którym powiązane będą zagadnienia środowiskowe $\mathrm{z}$ tradycyjnymi naukami. Należy opracować takie programy nauczania np. dotyczące proekologicznego zarządzania przedsiębiorstwem, które będą interdyscyplinarne i możliwe do wykorzystania w praktyce na potrzeby danego państwa.

\section{Podsumowanie}

Gospodarka oparta na wiedzy stwarza dogodne warunki w zakresie tworzenia i absporbcji informacji poprzez rozwój innowacji i kształcenia (systemu edukacji). W konsekwencji Polska musi zdefiniować i podnieś jakość swojej polityki w zakresie edukacji. Poprawie tej służyć będzie między innymi nałożenie na wyż- 
sze uczelnie obowiązku mianowania przedstawicieli biznesu na członków władz uniwersyteckich i komisji akademickich. Stworzy to zestaw bodźców w zakresie zatrudniania, utrzymywania i awansowania wykwalifikowanego personelu wywodzącego się spoza wyższych uczelni (Polska a gospodarka ..., 2004, s. 82-83).

„Nie będzie łatwo obudzić w człowieku,

takiej odpowiedzialności za świat,

która dotrzyma kroku rozwojowi cywilizacji.

Ale ci, którzy chcą, mogą zacząć już dziś.”

\title{
Vaclav Havel
}

\section{Piśmiennictwo}

Cichy D., Skuteczność kształcenia dla ekorozwoju, Biologia w Szkole, 1995 nr 5.

Сıсну D., Koncepcje społecznej edukacji ekologicznej, Biologia w Szkole, 1995 nr 5.

DoŁĘGA J.M., Z filozofii nauk ekologicznych. [w:] Ochrona środowiska społeczno - przyrodniczego w filozofii i teologii. Wydawnictwo Uniwersytetu Kardynała Stefana Wyszyńskiego. Warszawa 2003.

KALIŃski M., Edukacja ekologiczna formą przystosowania obronnego, [w:] „Edukacja i Dialog”, 1995, $\mathrm{nr} 6$.

Olaczek R., Słownik szkolny. Ochrona przyrody i środowiska. WSiP Warszawa 1999.

PARLAK M., Edukacja ekologiczna w procesie kształcenia wczesnoszkolnego - założenia, program, propozycje metodyczne, Wydawnictwo Pedagogiczne ZNP Kielce 2005.

Polska a gospodarka oparta na wiedzy - w kierunku zwiększenia konkurencyjności Polski w Unii Europejskiej, (2004), Bank Światowy Region Europy i Azji Środkowej Departament Rozwoju Sektora Prywatnego i Finansowego, Warszawa.

Tuszyńska L., Edukacja Ekologiczna dla nauczycieli i studentów, Wyższa Szkoła Pedagogiczna Towarzystwa Wiedzy Powszechnej Warszawa 2006.

http://www.poznajmyonz.pl/index.php?document=41

\section{The ecological education takes priority in the sphere of education nowadays}

\author{
SUMMARY
}

People never stop learning and developing their skills. Education is associated with various spheres and different moments of people's lives. The learning process is mainly linked with schools, however, we should not disregard that process which takes place outside schools as well. What we have learned, contributes, to a great extent, to what sort of people we are. The more we know, the more aware of the nearby world development, more aware of phenomena understanding, phenomena that take place around us and, therefore, allow us to participate in all society activities. 